\title{
TRANSFUSIONAL SUPPORT IN HSCT
}

\author{
Andrea Tiemi Kondo ${ }^{1}$, Karen Lima Prata ${ }^{2,3}$, Aline Miranda de Souza ${ }^{4}$, Sanny Marcele da Costa Lira ${ }^{4}$, \\ Andreza Alice Feitosa Ribeiro $5,6,7$ \\ 1 Hospital Israelita Albert Einstein - Departamento de Hemoterapia e Terapia Celular - 2 Fundação Hemominas \\ 3 Hospital das Clínicas da Universidade Federal de Minas Gerais - 4 Grupo Gestor de Serviços de Hemoterapia \\ 5 Unidade de Transplante de Medula Óssea do Hospital Israelita Albert Einstein - 6 Unidade de Transplante de Medula Óssea \\ do Instituto Nacional do Câncer - 7Unidade de Transplante de Medula Óssea do Hospital e Maternidade Brasil
}

\section{CELL THERAPY AND HEMOTHERAPY CONSENSUS}

\section{MOBILIZATION AND COLLECTION OF PERIPHERAL HEMATOPOIETIC PROGENITOR CELL (HPC)}

The mobilization of CD34+ cells for peripheral blood and the collection of peripheral hematopoietic progenitor cells mobilized by apheresis (HPC-A) is a crucial procedure and has as objective: the collection of an adequate number of HPC, the reduction of complications related to the collection, the prevention of failure and the optimization of available resources. $[1,2]$

\section{ALLOGENEIC TRANSPLANT}

\section{Mobilization with growth factor}

Use of Filgrastim (G-CSF) in the dose 10ug to 20/kg/ day in one or two administrations by subcutaneous route, for 4 to 5 days, with the first collection on day 4 or 5 . The last dose should preferably be administered 2 to 3 hours before the collection of the sample for the quantification of CD34+ cells in peripheral blood and 3 to 4 hours before the beginning of the apheresis procedure. ${ }^{[1]}$

The minimum dose of CD34+ cells to be collected and infused should be $2 \times 106 / \mathrm{kg}$ per transplant. Higher doses lead to faster grafting, on the other hand, very high doses are related to an increased incidence of chronic graft versus host disease (GVHDc). Therefore, the most appropriate target dose with current data varies between 4 and $5 \times 106 / \mathrm{kg}$ per transplant. ${ }^{[1}$ The collection of allogenic HPC-A should be whenever possible by peripheral venous access.

\section{AUTOLOGOUS TRANSPLANT}

\section{Mobilization with growth factor}

Filgrastim (G-CSF) at dose 10 to $20 \mathrm{ug} / \mathrm{kg} /$ day in one or two administrations by subcutaneous route, with the first collection on day 5. ${ }^{[1,2]}$ The last dose should be administered about 2 to 3 hours before sample collection for quantification of CD34+ cells in peripheral blood.

\section{Mobilization with chemotherapy}

Patients who have no indication for treatment with chemotherapy but who have risk factors or have failed to mobilize with the use of GCS-F can benefit from the association chemotherapy and G-CSF in the mobilization process. In this mobilization, cyclophosphamide (Cy) is usually used at a dose of 2 to 4 grams $/ \mathrm{m} 2$. Other options: vinorelbine $35 \mathrm{mg} / \mathrm{m}^{2}$ in single dose or etoposide $375 \mathrm{mg}$.

\section{Use of plerixafor}

Plerixafor can be used in association with G-CSF or chemotherapy + G-CSF regimens, in patients with high risk of failure or with previous history of mobilization failure, at a dose of $0.240 \mathrm{mg} / \mathrm{kg}$ of body weight, subcutaneous route the night before the collection, 9 to 12 hours before the quantification of CD34+ cells and apheresis collection. ${ }^{[2]}$

\section{Target dose of CD34+ cells to be collected}

The minimum dose of CD34+ cells to be infused should be $2 \times 106 / \mathrm{kg}$ per transplant. The optimal dose to be collected and infused is $5 \times 106 / \mathrm{kg}$ per transplant. ${ }^{[2]}$ 
Mobilization with G-CSF alone leads to a CD34+ cell peak between the 4th and 6 th day of use. ${ }^{[1]}$ For patients mobilized with chemotherapy+ G-CSF this quantification normally starts between the 8th and 10th day after the end of chemotherapy administration, during the hematological recovery phase, when the leukocyte count is over 1000 cells/uL. ${ }^{[2]}$

\section{HPC-A Collection (Autologous and Allogeneic)}

High volume apheresis (volume of blood processed more than 4 times the patient's volemia) consistently increases CD34+ collection yield in patients and improves final stem cell collection. However, electrolyte monitoring and replacement is important to avoid adverse reactions from hypocalcemia or hypopotassemia. In the case of allogeneic unrelated donation, it is recommended that a maximum of $24 \mathrm{~L}$ be processed in one or two consecutive days of collection in adult patients. ${ }^{[1]}$ In pediatric patients, who weigh less than $15 \mathrm{~kg}$ are usually transfused to achieve a target hemoglobin $(\mathrm{Hb})$ of $12 \mathrm{~g} / \mathrm{dL}$ and a platelet count of more than $40,000 / \mathrm{uL}$. The prime of the apheresis kit should be performed with red blood cells if their weigh is less than $20 \mathrm{Kg}$. Prophylactic transfusion of platelets is recommended if the platelet count is less than $30,000 / \mathrm{uL}$ and a processing proposal of at least three volemia is proposed. ${ }^{[2]}$

\section{BONE MARROW (BM) HARVEST}

Collection by apheresis has been the most used strategy to obtain progenitor cells for autologous and allogenic non-apparent transplants, the collection of bone marrow is an alternative collection for donors who do not accept mobilization with G-CSF or do not have adequate venous access. Allogeneic bone marrow collection has a lower incidence of graft versus host disease (GVHD) and should be the first option in patients with aplastic anemia. Bone marrow should not be the preferred source of HPC when cryopreservation is needed. In order to avoid dilution with peripheral blood, it is recommended to perform multiple punctures and aspirate the maximum volume of $5 \mathrm{mls}$ at each puncture. The syringes should be washed with a heparin solution at each aspiration. The volume to be collected should respect the target of $10-15 \mathrm{ml} / \mathrm{kg}$ of recipient, not exceeding the volume of $20 \mathrm{ml} / \mathrm{kg}$ of donor. ${ }^{[3]} \mathrm{It}$ is recommended to evaluate the need for pre-deposited autologous blood collection in allogeneic BM collections, to avoid donor exposure to allogeneic transfusion. ${ }^{[4}$ The recommended cell dose for bone marrow collection is total nucleated cell (TNC) $\geq 3 \times 10^{[8]} / \mathrm{kg}$ of nucleated cell and it is associated with a lower rate of graft failure. Minimum cell dose eecommended is
TNC $2 \times 10^{[8]} / \mathrm{kg}^{[4]}$ When red cell removal of bone marrow product is necessary such as due to major $A B O$ incompatibility or if it is cryopreserved, an attempt should be made to collect a larger volume, as there will be a loss of about $20 \%$ of the nucleated cells collected with processing.

\section{PROCESSING AND CRYOPRESERVATION OF HPC-A}

There are two main cryoprotective solutions used in HPC freezing. A) Dimethylsulfoxide (DMSO) associated with a protein source (autologous plasma or human albumin) combined with an equal volume of cells in order to obtain a final DMSO concentration of $10 \%$. B) DMSO associated with hydroxetilamide (HES) and a protein source, usually human albumin, in final concentrations of $5 \%, 6 \%$ and $4 \%$, respectively. ${ }^{[6,7]}$ Studies indicate that the solution that associates HES with DMSO is superior to the one that uses DMSO alone. EBMT recommends the association of ACD-A cryoprotectant solution at a dose of 0.05 to $0.25 \mathrm{~mL}$ per $\mathrm{mL}$ of product to reduce the risk of lump formation. ${ }^{[5]}$

Regarding the concentration of nucleated cells for cryopreservation of HPC, some centers prefer to perform cryopreservation in low doses, i.e., with the final concentration between 100 and $200 \times 106$ cells/ $\mathrm{mL} .8$ Other centers have already demonstrated that the final concentration up to $300 \times 106$ cells $/ \mathrm{mL}$ is safe. 9 The ideal rate of freezing of HCT is 1 to $2^{\circ} \mathrm{C}$ per minute. Ideally, equipment should be used that allows freezing of the bags at programmed temperature, but many centers have opted for the use of mechanical freezers at minus $80^{\circ} \mathrm{C}$. ${ }^{[6,10]}$

\section{Storage}

The products can be stored in a mechanical freezer with a temperature between $-80^{\circ} \mathrm{C}$ and $-150^{\circ} \mathrm{C}$ or in tanks containing liquid nitrogen or vapor phase. Storage in freezers at $-80^{\circ} \mathrm{C}$ has been increasingly used, when the transplant will be performed in a few weeks or months after cryopreservation, however there are reports of clinical use of cryopreserved bags with DMSO + HES in freezers at $-80^{\circ} \mathrm{C}$ for up to 4148 days. ${ }^{[10]}$ Tanks containing liquid nitrogen appear to be safer in maintaining temperature however, additional care is required in this type of storage due to the risk of cross contamination between products..$^{[11]}$

\section{4-TRANSPORT, THAWING AND INFUSION OF HPC}

The transport must take place in rigid, resistant outer packaging of adequate size to the volume of bags to be transported. 
For fresh products: The temperature should be kept between 2 and $24^{\circ} \mathrm{C}$ positive (preferably close to $\left.4^{\circ} \mathrm{C}\right)$. And the total time between the end of the collection and the beginning of the infusion should not exceed 48 hours. For cryopreserved products in a mechanical freezer $\left(-80^{\circ} \mathrm{C}\right)$, the temperature must be kept at or below $-65^{\circ} \mathrm{C}$ until the moment of thawing, and for cryopreserved products in nitrogen $\left(-150^{\circ} \mathrm{C}\right)$, the bags must be kept at a temperature of less than $-130^{\circ} \mathrm{C}^{[12]}$

Thawing: To reduce the risk of serious adverse events, ideally the maximum DMSO volume is $1 \mathrm{ml} \mathrm{DMSO} / \mathrm{Kg}$ receiver weight/day. If the DMSO volume is higher than this limit, consider dividing the infusion into two or more consecutive days. For pediatric patients, especially those of lower weight, removal of DMSO may reduce the risk of adverse effects. ${ }^{[13]}$

Pre medication: The hydration as well as the use of mannitol before the HPC infusion, leads to an increase in diuresis and prevents renal damage caused by the deposit of free hemoglobin present in the product to be infused. Diphenhydramine, dipyrone and hydrocortisone are often administered to prevent allergic, non-hemolytic fevers and/or DMSO-related reactions. ${ }^{[13]}$

Thawing: Cryopreserved products should be thawed in a water bath with distilled water or saline at $37^{\circ} \mathrm{C}$ $\left(+-1^{\circ} \mathrm{C}\right)$. The use of sterile plastic bags during thawing process can help reduce contamination in cases of bag breakage and product leakage.

Infusion: Transfusion equipment without leukocytes filter should be used for infusion and the recommended rate is $10 \mathrm{~mL} /$ minute for thawed products and $6 \mathrm{~mL} /$ $\mathrm{Kg}$ of receiver weight/hour for fresh products.

Reactions related to DMSO: DMSO is the main cause of adverse events during the infusion of cryopreserved products. The administration of $>1 \mathrm{ml} / \mathrm{kg}$ DMSO in 24 hours is the recommendation for the prevention of adverse events. Patients often report coughing, and taste of preservative during administration, which can be reversed by reducing the infusion rate. Changes in vital signs can be observed such as hypertension, tachycardia or bradycardia.

\section{Cytokine Release Syndrome}

Cytokine release syndrome is a systemic inflammatory response syndrome related to immune hyperstimulation or aberrant immune activation, leading to elevated levels of cytokines and inflammation. This complication can present mild symptoms of fever and chills, but it can sometimes lead to severe conditions with hemodynamic instability, which can culminate in multiple organ failure. ${ }^{[14]}$ Non-infectious fevers occur in $80 \%$ to $90 \%$ of haploidentical transplant recipients between days 0 and +6 . They usually refer soon after administration of cyclophosphamide and are associated with class II incompatibility and higher CD3 + graft cell dose. ${ }^{[15]}$

\section{5-TRANSFUSION SUPPORT IN BONE MARROW TRANSPLANTATION (BMT)}

As general recommendation, blood transfusion (RBC concentrates and platelet concentrates) intended for BMT candidate patients should be leukoreduced, i.e., contain less than $5.0 \times 106$ leukocytes per unit aiming at preventing non- hemolytic febrile reaction and anti-HLA alloimmunization. For prevention of CMV, the recommendation is leukoreduction or the use of blood products from seronegative donors for $\mathrm{CMV} \cdot{ }^{[16]}$

In addition, these blood components and granulocyte concentrates should be irradiated to prevent transfusional GVHD. ${ }^{[17]}$ The duration of use of irradiated products should be based on the time of immune reconstitution of the patient and in general for autologous BMT should be initiated at least 2 weeks before collection of HPC and extend to 3 months after transplantation and for allogeneic BMT at least before the onset of conditioning to 6 months after transplantation.

\section{SPECIAL SITUATIONS}

\section{Platelet Refractory (RP)}

Patients submitted to BMT may develop platelet refractoriness after repeated transfusions of allogeneic platelet concentrates. Their causes may be non-immune ( $>80 \%$ of cases) and immune $(<20 \%$ of cases). 18

The diagnosis can be confirmed by calculation of platelet increment $(\mathrm{CCl})$ after transfusion of recent platelets ( $<48$ hours of collection), identical ABO verified in two different and preferably subsequent moments. ICC values below 5000/ $\mu$ l collected between 15 minutes and 1 hour after transfusion (1hour ICC) or ICC values below $2500 / \mu$ l collected between ${ }^{[18]}$ and 24 hours after transfusion (24hour ICC) define the case as platelet refractory.

The management of PR involves the suspension of non-immune factors, when possible, the research of anti-HLA class I antibodies which is responsible for $80 \%$ of the cases of immune PR, in addition to the 
cross-examination with patient serum. In immune PR it is recommended the use of platelet concentrate compatible with the antibody identified in the receptor ${ }^{[19]}$, ideally compatible with the four antigens (HLA-A and HLA-B). When the response is unsatisfactory other causes such as anti-HPA or non-immune factors should be investigated.

\section{Granulocyte transfusion}

Granulocyte transfusion is used to prevent infections in patients with neutropenia or neutrophil function disorders ${ }^{[20]}$ and to treat severe neutropenia (granulocytes $<500 / \mu \mathrm{L}$ ) associated with bacterial and fungal infections that are not responsive to appropriate antibiotic therapy and of broad spectrum. However, there are still no randomized studies that prove its clinical efficacy in treating infections and that demonstrate improved survival. ${ }^{[20,21]}$

The process for granulocyte transfusion requires some care with the donor, product, and recipient. In general, candidates for donation must follow the same clinical criteria of suitability as a conventional blood donation, have carried out laboratory screening for infectious diseases transmissible by blood within 72 hours of collection and receive mobilizing agents (corticosteroids and G-CSF) at least 12 hours before collection. The granulocyte concentrate collected by apheresis, must contain above $1 \times 1010$ leukocytes/unit/dose for an adult recipient and have $A B O$ compatibility respected. It should be infused irradiated and as soon as possible after the collection is completed. ${ }^{[22]}$

\section{6-ALLOGENEIC BMT WITH ABO INCOMPATIBIL- ITY}

Approximately $30 \%$ of allogenic related transplants and $50 \%$ of unrelated transplants will have some degree of $\mathrm{ABO}$ incompatibility.

The main immuno-hematological consequences of ABO-incompatible transplants are summarized in table 2.

TABLE 2 - Immuno-hematological consequences of ABO TCTH incompatible

\begin{tabular}{|c|c|c|}
\hline ABOIncompatibility & Consequences & Causes \\
\hline \multirow{4}{*}{ Major } & Acute hemolytic response & Infusion of incompatible red blood cell \\
\hline & $\begin{array}{c}\text { Delay in the grafting of granulocytes and } \\
\text { platelets }\end{array}$ & $\begin{array}{l}\text { Loss of progenitor cells hematopoietic in the } \\
\text { process of RBC removal of the product. }\end{array}$ \\
\hline & Delay in erythroid grafting & Presence osf isohemaglutinin anti d-nor \\
\hline & Pure aplasia of red series & Persistence of anti-donor isohemoaglutinin. \\
\hline \multirow[b]{2}{*}{ Minor } & Acute hemolysis & High isohemaglutinin titles in donor plasma \\
\hline & Late hemolytic reaction & $\begin{array}{l}\text { Donor B lymphocytes producing anti- } \\
\text { receptor isohemaglutinin (passage } \\
\text { lymphocyte syndrome) }\end{array}$ \\
\hline
\end{tabular}




\section{CONDUCT TO MINIMIZE THE RISKS OF INFUSION:}

The risks of infusion of the product with $A B O$ incompatibility can be minimized by manipulation of the graft associated or not with measures to reduce the anti-donor isohemoagglutinins circulating in the recipient and by adequate hemotherapic support.

TABLE 3 - Procedures for handling TCPH with ABO incompatibility. Modified from Worel, 2016

\begin{tabular}{|c|c|c|}
\hline ABO incompatibility & Grafting manipulation & Receiver care \\
\hline \multicolumn{3}{|c|}{ Major } \\
\hline & $\begin{array}{c}\text { HPC-BM } \\
\text { RBC removal of product }\end{array}$ & \multirow[b]{2}{*}{$\begin{array}{l}\text { - Infusion of plasma with donor ABO type } \\
\text { - Therapeutic Plasmapheresis } \\
\text { - Proper hemotherapic support }\end{array}$} \\
\hline $\begin{array}{l}\text { Receiver with title of } \\
\text { isohemoaglutinin anti-donor } \geq 1: 32\end{array}$ & $\begin{array}{c}\text { HPC-A } \\
<20 \mathrm{~mL} \text { red cells: infusion without } \\
\text { manipulation } \\
\geq 20 \mathrm{~mL} \text { red cells: deseritrocitation }\end{array}$ & \\
\hline $\begin{array}{l}\text { Receiver with title of } \\
\text { isohemoaglutinin anti-door } \leq 1: 16\end{array}$ & $\begin{array}{c}\text { HPC-BM } \\
\text { RBC removal* } \\
\text { HPC-A } \\
\text { Infusion without manipulation }\end{array}$ & Proper hemotherapic support \\
\hline \multicolumn{3}{|l|}{ Minor } \\
\hline $\begin{array}{c}\text { Donor with isohemaglutinin title } \\
\text { anti receiver } \geq 1: 256\end{array}$ & $\begin{array}{l}\text { HPC-BM or HPC-A } \\
\text { Plasma removal }\end{array}$ & Proper hemotherapic support \\
\hline \multirow{2}{*}{$\begin{array}{l}\text { Donor with isohemaglutinin title } \\
\text { anti receiver } \leq 1: 128\end{array}$} & $\begin{array}{c}\text { HPC-BM } \\
\text { Plasma removal }\end{array}$ & \multirow{2}{*}{ Proper hemotherapic support } \\
\hline & $\begin{array}{c}\text { HPC-A } \\
\text { Infusion without manipulation }\end{array}$ & \\
\hline
\end{tabular}

* Some centers have opted for infusion without manipulating the graft. HPC-A = hematopoietic progenitor cells of mobilized peripheral blood collected by apheresis; HPC-BM $=$ hematopoietic progenitor cells from bone marrow.

\section{Red blood cell removal}

It consists of the process of removing erythrocytes from the product to be infused. It can be manual or automated, however, to minimize the costs of the process, most services use the manual technique, with the help of a sediment agent, usually the hydroxyethyl starch (HES) at $6 \%$ of high molecular weight, added to the product in the proportion 1:4 to $1: 8$. There is no consensus on the maximum volume of red blood cells to be safely infused. Most ser- vices limit this volume to 10 to $40 \mathrm{~mL}$ for adults. In pediatrics, some authors recommend transfusion of up to $0.4 \mathrm{~mL} / \mathrm{Kg}$ and others consider infusion of up to $3 \mathrm{~mL} / \mathrm{Kg}$ safe. ${ }^{[24]}$

\section{Plasma Removal}

Removal of excess plasma from the product by centrifugation (400 to $4000 \mathrm{xg}$ for 10 to 20 minutes). The cellular loss in this process is usually less than $5 \%$. 


\section{Reduction of the isohemoagglutinins anti donor of the receiver}

It is possible to reduce the titration of the anti-donor isohemoagglutinides circulating in the receptor by means of therapeutic plasmapheresis or by infusion of secretory plasma, $A B$ or isogroup with the donor. ${ }^{[25.26]}$ The American Society of Apheresis (ASFA) considers the indication of plasmapheresis in BMT with $A B O$ major or bidirectional incompatibility as category II with GRADE 1B for HPC-BM and GRADE 2B for HPC-A and guides the performance of the procedure before the infusion of the graft, with human plasma or albumin or a combination of these.

\section{7 - DONOR LYMPHOCYTE INFUSION (ILD)}

Infusion of donor lymphocytes (ILD) may be requested in cases of relapse of disease, reduction of chemotherapy, viral infections difficult to control, among others. ${ }^{[27]}$ The efficacy of lymphocyte infusion varies according to the type and volume of the underlying disease, leading to $70-80 \%$ complete response in cases of cytogenetic or hematologic relapse of acute myeloid leukemia (CML) while less than $40 \%$ of patients with recurrent acute leukemia respond to the ILD. ${ }^{[28]}$

\section{Donor evaluation:}

The medical evaluation of the donor prior to the collection of lymphocytes is mandatory under current legislation and the eligibility criteria are the same used for blood donors, and serology for cytomegalovirus (CMV).

\section{Lymphocyte collection:}

Lymphocytes can be obtained from the buffy coat of whole blood, however, the collection through apheresis equipment can offer a greater amount of CD3+ cells and is the most used. For the apheresis cell collection process, an adequate venous access should be obtained and the need for central venous catheter implantation should be avoided. Each apheresis session should process 2 to 2.5 volemia and if the number of cells needed is not obtained, a second procedure can be performed ${ }^{[29]}$

\section{Donor Mobilization:}

There is no need for any medication to collect lymphocytes from the donor, however, when the ILD is programmed (prophylactic) or highly probable, a small aliquot of the product obtained for $\mathrm{CTH}$ collection for transplantation can be separated.

Some studies show that previous use of G-CSF promotes $T$ cell hyperresponsiveness, with polarization to the Th2 strain, induction of regulatory $T$ cells and tolerogenic dendritic cells, which reduces the risk of graft disease against the host and maintains the benefits of graft cells against the disease ${ }^{[30]}$. Some centers choose to use CD3+ cells obtained on the day of CTH collection for transplantation, as long as the collection was by apheresis,

\section{Storage of collected cells:}

The collected cells should be kept refrigerated and preferably transfused as soon as possible after collection in case of fresh infusion.

\section{Doses and treatment schemes:}

The dose of lymphocytes to be infused depends on the type of BMT, patient or disease, and should be defined by the transplant team taking into consideration the potential risk of GVHD, as well as the aggressiveness of the disease to be treated. Patients at higher risk of developing GVHD, such as those undergoing hapalodectid transplantation, can start infusions with a low dose : 1 x 105 CD3+/Kg cells from the recipient for preemptive use. ${ }^{[31]}$

.For therapeutic use, a staggered dose regimen starting with the $1 \times 106 \mathrm{Cd} 3+/ \mathrm{Kg}$ dose of the recipient, and subsequent doses of $5 \times 106,1 \times 107,5 \times 107$ $\mathrm{Cd} 3+/ \mathrm{Kg}$ cells of the recipient is the most commonly used. The interval between doses can vary from 3 weeks to 3 months and, as well as the dose increase, will depend on the response of the patient and the degree of graft disease against the host. ${ }^{[30,31]}$

\section{8-ANTI-HLA DONOR DESENSITIZATION PROTOCOLS WITH HLA INCOMPATIBILITY.}

The presence of donor-specific anti-HLA antibody (HLA De) is associated with grafting failure. ${ }^{[32]} \mathrm{Re}-$ search for these antibodies is indicated for partial HLA compatible transplants and haploidemic transplants. The risk of grafting failure depends on the level of antibodies detected and the properties this antibody presents. Polytransfused and multiparous patients are more likely to present antibodies. Whenever possible, another donor should be tried for which the patient does not present anti-HLA De antibody. ${ }^{[33]}$

The presence of anti-HLA De antibodies with MFI (Mean Fluorescence Intensity) above 2000 is an indication of desensitization protocols to reduce or eliminate these antibodies, which should be discussed among BMT team, hemotherapy team and histocompatibility laboratory. The strategies involve: 
Depletion of antibody producing cells: a) use of rituximab (action on B lymphocytes): ( $375 \mathrm{mg} / \mathrm{m} 2) 1$ day after intravenous immunoglobulin; b) Bortezomib (action on plasma cells): optional medication, being done 3-4 applications before starting plasmapheresis, therefore about 3 weeks before the start of conditioning.

Reduction of antibodies already formed - plasmapheresis: generally 3 sessions with exchange of 1.5 plasma volemia and replacement of $100 \%$ volume with $5 \%$ albumin before starting the conditioning. It cannot be performed during conditioning or on $\mathrm{D}+3$ and $\mathrm{D}+4$ when the cyclophosphamide is infused in haploid transplants. Another plasmapheresis session can be performed on D-1 if anti-HLA antibodies persist until this preterm and strategy phase.

Neutralization of antibodies with: a) Intravenous immunoglobulin (IgEV): $1 \mathrm{~g} / \mathrm{kg}$ performed one day after the last session of plasmapheresis; b) infusion of leukocytes irradiated from the donor ("buffy coat"): obtained from a unit of whole blood from the donor collected in D-2, about $40-50 \mathrm{ml}$ of buffy coat is administered the day before the infusion. The inclusion of this technique has obtained good results, even when the use of plasmapheresis and EV immunoglobulin has not decreased or eliminated the Anti- HLA De antibodies. An option to obtain the buffy coat of whole blood is the use of $40 \mathrm{ml}$ of the bag of hematopoietic peripheral blood progenitor cells collected 1 day before the infusion. ${ }^{[34]}$

The combination and number of strategies used will depend on the risk and level of anti- HLAde antibodies. Some factors are considered additional risks: presence of multiple antibodies, presence of the same anti-HLA mismatch from a previous transplant and son-to-mother donation. ${ }^{[3]}$ The reduction of anti-HLA antibodies and should be monitored during the protocol: after the plasmapheresis, before starting the conditioning and before the infusion of hematopoietic progenitor cells and after the infusion. Patients may have increased levels of anti-HLA antibodies on D-1 (rebound), in which case 1 or 2 additional sessions of plasmapheresis and/or intravenous immunoglubulin may be performed on $D+1$ and $D+2$ days. The choice protocol should take into account the risk of graft failure, higher than those with anti-HLA antibody $>5000 \mathrm{MFI}$ and antibody persistence during conditioning. Use of buffy coat should be considered in patients with very high levels of MFI or persistence of antibodies after other techniques used.

\section{9-INDICATION OF PHLEBOTOMY IN IRON OVERLOAD POS BMT}

After the transplant, patients may have iron overload due to transfusion support, which will not be eliminated without therapeutic intervention. Results from studies on the impact of iron overload on thalassemia and the normal population indicate the need for normal iron levels in the post TMO period. In the chaos with ferritin above $2500 \mathrm{ug} / \mathrm{L}$, transferrin saturation close to $100 \%$, there is a high risk of liver damage and irreversible tissue damage. ${ }^{[35]}$

With erythropoesis re-established after a successful transplant, phebotomy is a therapeutic option to drug treatment, being a safe, effective, low cost alternative, but only applicable to patients with sustained hematopoiesis, and cannot be used in the immediate phases of transplant. Iron chelators can be used, but it is a more expensive alternative and requires care due to renal toxicity, when used in conjunction with cyclosporine. ${ }^{[36]}$

\section{0 - ACCREDITATION OF HEMOTHERAPY AND CELL THERAPY SERVICES}

Any health care, especially the more complex ones such as haematopoietic stem cell transplantation and other forms of cell therapy, needs some elements to achieve good health care, such as: registration of activities that make it possible to identify improvements in care and research practice; implementation and monitoring of practices based on quality standards and reporting and dissemination of treatment results applied to patients.37 Although hematopoietic stem cell transplantation has

evolved a lot in the last 50 years, this procedure is still associated with high morbidity and mortality. 38 Another aspect that requires much attention is the use of healthy donors, family or not, in the therapeutic process.

Internationally, there are 2 organizations that have defined standards and accreditations in these 3 areas: FACT (Foundation for the Accreditation of Cellular Therapy) in the United States of America founded in 1996 and JACIE (Joint Accreditation Committee of ISCT), founded in 1999 by ISCT and EBMT.

Generally the patterns of operation are defined in three major areas: 1- collection of cells for transplantation or cell therapy; 2- laboratory processing, storage, distribution and infusion of hematopoietic cells and 3-clinical part of patient care during the transplantation period. The requests can be partial for all 
3 areas or separately: be global for adults and pediatrics or separately. In all 3 sessions are addressed aspects such as requirements for the facilities; training of personnel and training; quality control of inputs used; control of updating and implementation of technical procedures; evaluation, selection and care of the donor; databases and registration, and

\section{REFERENCES}

1.Hien K. Duong, Bipin N. Savani, Ed Copelan, Steven Devine, Luciano J. Costa, John R. Wingard, etal. , Peripheral Blood Progenitor Cell Mobilization for Autologous and Allogeneic Hematopoietic Cell Transplantation: Guidelines from the American Society for Blood and Marrow Transplantation, Biology of Blood and Marrow Transplantation, Volume 20, Issue 9, 2014, Pages. v.20, p.1262-1273, 2014.

2.Yuan, S. and Wang, S. How do we mobilize and collect autologous peripheral blood stem cells?. Transfusion v,57, p.13-23, 2017.

3.Schiffer CA, Bohlke K, Delaney M, Hume H, Magdalinski AJ, McCullough JJ, Omel JL, Rainey JM, Rebulla P, Rowley SD, Troner MB, Anderson KC. Platelet Transfusion for Patients With Cancer: American Society of Clinical Oncology Clinical Practice Guideline Update. J Clin Oncol it. v.36, p.283-299, 2018.

4.Gorin NC. Bone Marrow Harvesting for HSCT. In: Carreras E, Dufour C, Mohty M, Kröger N, editors. The EBMT Handbook: Hematopoietic Stem Cell Transplantation and Cellular Therapies. 7th edition: Springer; 2019. Chapter 14.

5.Wuchter P. Processing, Cryopreserving and Controlling the Quality of HSCs. In: Carreras E., Dufour C., Mohty M., Kröger N., eds. The EBMT Handbook. Hematopoietic Stem Cell Transplantation and Cellular Therapies. 2019 ed. Cham: Springer; 2020. p.127-130, 127- 130.

6.Hornbergerb K., Yua G., McKennac D., et al. Cryopreservation of Hematopoietic Stem Cells: Emerging Assays, Cryoprotectant Agents, and Technology to Improve Outcomes. Transfus Med Hemother. v.46, p.188-196, 2019. doi: 10.1159/000496068.

7.Rowley S.D., Feng Z., Chen L., et al. A randomized phase III clinical trial of autologous blood stem items appropriate to each session. The continuous evaluation of the program performance is based on the analysis of specific indicators such as morbidity, mortality, incidence of adverse events in the area and the reporting of data to National Centers, for example, RBT and International (CIBMTR).38

cell transplantation comparing cryopreservation using dimethylsulfoxide vs dimethylsulfoxide with hydroxyethylstarch. Bone Marrow Transplant. v.31, p. 1043-1051, 2003.

8.Bakken A.M. Cryopreserving Human Peripheral Blood Progenitor Cells. Current Stem Cell Research \& Therapy. v.1, p.47-54, 2006.

9.Martin-Henao G.A., Torrico C., Azqueta C., et al. Cryopreservation of hematopoietic progenitor cells from apheresis at high cell concentrations does not impair the hematopoietic recovery after transplantation. Transfusion. v.45, p.1917-1924, 2005. doi: 10.1111/j.1537-2995.2005.00643.x.

10.Detry G., Calvet L., Straetmans N. et al. Impact of uncontrolled freezing and long-term storage of peripheral blood stem cells at $-80^{\circ} \mathrm{C}$ on haematopoietic recovery after autologous transplantation. Report from two centres. Bone Marrow Transplant. .v.49, p.780-785, 2014. doi:10.1038/ bmt.2014.53.

11.Tedder R.S., Zuckerman M.A, Goldstone A.H., et al. Hepatitis $B$ transmission from contaminated cryopreservation Tank. Lancet. it. v. 346, p.137140, 1995.

12.Diretoria Colegiada da Agência Nacional de Vigilância Sanitária. Resolução de Diretoria Colegiada no 214 de 7 de fevereiro de 2018. Diário da Uniãon ${ }^{\circ}$ 36, de 22 de fevereiro de 2018 \& Diretoria Colegiada da Agência Nacional de Vigilância Sanitária. - Resolução de Diretoria Colegiada no 20, de 10 de abril de 2014. Diário da União. n.70, 2014.

13.Shu Z, Heimfeld S, Gao D. Hematopoietic SCT with cryopreserved grafts: Adverse reactions after transplantation and cryoprotectant removal before infusion. Vol. 49, Bone Marrow Transplantation. v. 49, p.469-476, 2014.

14.Lee DW, Gardner R, Porter DL, et al. Current con- 
cepts in the diagnosis and management of cytokine release syndrome. Blood, 124 v. 124, p.188195, 2014.

15.McCurdy SR, Muth ST, Tsai HL, et al. Early fever after haploidentical bone marrow transplantation correlates with class II HLA-mismatching and myeloablation but not outcomes. Biol Blood Marrow Transplant. v.24, n.10, p.2056-2064, 2018.

16.Christou G, lyengar A, Shorr R, Tinmouth A, Saidenberg $E$, Maze $D$, et al. Optimal transfusion practices after allogeneic hematopoietic cell transplantation: a systematic scoping review of evidence from randomized controlled trials. Transfusion. v.56, n.10, p.2607-2614, 2016.

17.Kopolovic I, Ostro J, Tsubota H, Lin YL, Cserti-Gazdewich CM, Messner HA, et al. A systematic review of transfusion-associated graft-versushost disease. Blood. v. 126, n. 3, p.406-414, 2015.

18.Pavenski K, Freedman J, Semple JW. HLA alloimmunization against platelet transfusions: pathophysiology, significance, prevention and management. Tissue Antigens. v.79,n.4, p.237245, 2012.

19.Juskewitch JE, Norgan AP, De Goey SR, Duellman PM, Wakefield LL, Gandhi MJ, et al. How do I ... manage the platelet transfusion-refractory patient? Transfusion. v.57, n.12, p. 2828-2835, 2017.

20.Price TH, Boeckh M, Harrison RW, McCullough J, Ness PM, Strauss RG, et al. Efficacy of transfusion with granulocytes from G-CSF/dexamethasone-treated donors in neutropenic patients with infection. Blood. v.126, n.18, p.2153-2161, 2015.

21.Cancelas JA. Granulocyte transfusion: questions remain. Blood. v.126, 18, p.2082-2083, 2015.

22.Estcourt LJ, Stanworth SJ, Hopewell S, Doree C, Trivella M, Massey E. Granulocyte transfusions for treating infections in people with neutropenia or neutrophil dysfunction. Cochrane Database of Systematic Reviews. n.4, 2016.

23.Worel N. ABO-Mismatched Allogeneic Hematopoietic Stem Cell TransplantationTransfus Med Hemother. v.43, p.3-12, 2016. doi:10.1159/000441507

24.Patrick K., Lau W., Gassas A. et al. Major ABO incompatible BMT in children: determining what residual volume of donor red cells can safely be infused following red cell depletion.
Bone Marrow Transplant. v. 50, p.536-539, 2015. doi:10.1038/bmt.2014.309

25.Sheppard, D.; Tay J., Bryant A., et al. Major ABO-incompatible $\mathrm{BMT}$ : isohemagglutinin reduction with plasma exchange is safe and avoids graft manipulation. Bone Marrow Transplant. v.48, p.953-957, 2013. doi:10.1038/bmt.2012.264.

26.Quek J., Lee J.J., Lim F.L. et al. Donor-type fresh frozen plasma is effective in preventing hemolytic reaction in major $A B O$ incompatible allogeneic stem cell transplant. Transfusion. v.59, p.335-339, 2019.

27.Chalandon Y, Passweg JR, Schmid C, Olavarria E, Dazzi F, Simula MP, et al. Outcome of patients developing GVHD after DLI given to treat CML relapse: A study by the chronic leukemia working party of the EBMT. Bone Marrow Transplant. 2010.

28.Yan CH, Liu DH, Liu KY, Xu LP, Liu YR, Chen H, et al. Risk stratification-directed donor lymphocyte infusion could reduce relapse of standard-risk acute leukemia patients after allogeneic hematopoietic stem cell transplantation. Blood. 2012.

29.AABB (American Association of Blood Banks). Cellular Therapy: Principles, Methods, and Regulations. 2nd editio. Areman, Ellen M.; Loper K, editor. 2016.

30.Wen Q, Kong Y, Zhao HY, Zhang YY, Han TT, Wang $Y$, et al. G-CSF-induced macrophage polarization and mobilization may prevent acute graft-versus-host disease after allogeneic hematopoietic stem cell transplantation. Bone Marrow Transplant. 2019.

31.Zeidan AM, Forde PM, Symons $H$, Chen A, Smith $B D$, Pratz K, et al. HLA- Haploidentical donor lymphocyte infusions for patients with relapsed hematologic malignancies after related HLA-haploidentical bone marrow transplantation. Biol Blood Marrow Transplant. 2014;

32. Yoshihara S, Maruya E, Taniguchi K, Kaida K, Kato R, Inoue T, et al. Risk and prevention of graft failure in patients with preexisting donor-specific HLA antibodies undergoing unmanipulated haploidentical SCT. Bone Marrow Transplant. v.47, p.508-515, 2012.

33.Ciurea SO, Thall PF, Milton DR, Barnes TH, Kongtim P, Carmazzi $Y$, et al. Complement-binding donor-specific anti-HLA antibodies and risk of primary graft failure in hematopoietic stem cell 
transplantation. Biol Blood Marrow Transplant v. 21, n. 8, p. 2015.

34.Ciurea SO., Cao K, Fernandez-Vina M, et al. The European Society for Blood and Marrow Transplantation (EBMT) Consensus Guidelines for the Detection and Treatment of Donor specific Anti-HLA Antibodies (DSA) in Haploidentical Hematopoietic Cell Transplantation. Bone Marrow Transplant. v. 47, p.508-515, 2018.

35.Coates TD, Carson S, Wood JC, et al. Management of iron overload in hemoglobinopathies: what is the appropriate target iron level? Ann N Y Acad Sci. it. v.1368, p.95-106, 2016.
36.Kontoghiorghes GK. How to manage iron toxicity in postallogeneic hematopoietic stem cell transplantation?,2020 Expert Review of Hematology, v.13, n.4, p.299-300, 2020.

37.LeMaistre CF, Wacker KK, Akard LP et al. Integration of Publicly Reported Center Outcomes into Standards and Accreditation: The FACT Model. Biol Blood Marrow Transplant. v.13, p.2243-2250, 2019.

38.Snowden JA, McGrath E, Duarte RF., R Saccardi R et al. JACIE accreditation for blood and marrow transplantation: past, present and future directions of an international modelfor healthcare quality improvement. Bone Marrow Transplant. v.52, p.1387-1371, 2017. 